\title{
Analisis Peningkatan Kualitas Permukiman Kumuh Kelurahan Tallo Kecamatan Tallo Kota Makassar
}

\author{
Analysis of Improving the Quality of Slum Settlements of Tallo Village, Tallo District, \\ Makassar City \\ St. Nurhalizah Mardjuni ${ }^{1}$, Syafri $^{1,2}$, Rahmawati Rahman ${ }^{1}$ \\ ${ }^{1}$ Program Studi Perencanaan Wilayah dan Kota, Fakultas Teknik, Universitas Bosowa \\ ${ }^{2}$ Program Studi Pascasarjana Perencanaan Wilayah dan Kota, Fakultas Teknik, Universitas Bosowa \\ Email : mardjuniliza@gmail.com
}

\section{Artikel info}

\section{Artikel history:}

Diterima; 25-10-2020

Direvisi: $12-11-2020$

Disetujui;13-11-2020

\begin{abstract}
This study aimed to identify the causes of slum settlements and to find out strategies to improve the quality of slum settlements in Tallo Village, Makassar City. This research was conducted with literature studies and field studies with research variables in the form of drainage, drinking water, waste water, and solid waste. The data obtained were analyzed using the chi-square analysis method, analysis of internal and external factors (IFE-EFE), IE matrix, and SWOT analysis. Based on the results of the study, it was found that the source of drinking water and the need for drinking water had a strong effect on the causes of slum, while wastewater and garbage had a moderate effect on the causes of slum. The strategy for improving the quality of slum settlements in Tallo Sub-District, Makassar City is to take advantage of communities that support government programs related to activities to improve the quality of their settlement environments with the existence of MENTRI Decree No. 534 / KTPS / M / 200 Regarding settlement arrangement, utilizing public awareness in improving the quality of Slum Settlements in accordance with PU Regulation No.2 of 2016 concerning improving the quality of housing and slum settlements, maintaining existing road networks such as in RT RW MAKASSAR CITY 2015 -2035 regarding the development, enhancement, stabilization and rehabilitation of road networks, as well as increasing the socio-economic potential of the surrounding community with community empowerment programs (RP2KPKP, KOTAKU, and Mayor Kumuh Decree 2015).
\end{abstract}

Abstrak. Tujuan dari penelitian ini ialah mengidentifikasi penyebab permukiman kumuh dan mengetahui strategi peningkatan kualitas permukiman kumuh di Kelurahan Tallo Kota Makassar. Penelitian ini dilakukan dengan studi kepustakaan dan studi lapangan dengan variabel penelitian berupa drainase, air minum, air limbah, dan persampahan. Data yang diperoleh dianalisis menggunakan metode analisis chi-square, analisis faktor-faktor internal dan eksternal (IFE-EFE), matriks IE, serta analisis SWOT. Berdasarkan hasil penelitian diperoleh bahwa sumber air minum dan kebutuhan air minum berpengaruh kuat terhadap penyebab kekumuhan, sedangkan air limbah dan persampahan berpengaruh sedang terhadap penyebab kekumuhan. Adapun strategi peningkatan kualitas permukiman kumuh di Kelurahan Tallo Kota Makassar ialah memanfaatkan masyarakat yang mendukung program pemerintah terkait kegiatan peningkatan kualitas lingkungan permukimannya dengan adanya SK MENTRI NO 534/KTPS/M/200 Tentang penataan permukiman, memanfaatkan kesadaran masyarakat dalam meningkatkan kualitas Permukiman Kumuh sesuai dengan Permen PU NO 2 Tahun 2016 tentang peningkatan kualitas perumahan dan permukiman kumuh, merawat jaringan jalan yang sudah ada seperti pada 

peningkatan, pemantapan,dan rehabilitasi jaringan jalan, serta meningkatkan potensi sosial ekonomi masyarakat sekitar dengan program pemberdayaan masyarakat (RP2KPKP, KOTAKU, dan SK Kumuh Walikota 2015).

\begin{tabular}{lr}
\hline Keywords: & Coresponden author: \\
Slum settlements; & Email: mardjuniliza @ gmail.com \\
drainage; & (1) \\
drinking water; & (i) \\
waste water; & artikel dengan akses terbuka dibawah lisensi CC BY -4.0 \\
solid waste & \\
\hline
\end{tabular}

\section{PENDAHULUAN}

Sebagaimana diamanatkan dalam Perubahan Kedua Undang Undang Dasar Negara Republik Indonesia tahun 1945, yang ditetapkan pada tanggal 18 Agustus tahun 2000, dalam pasal $28 \mathrm{H}$ ayat (1) disebutkan bahwa : "Setiap orang berhak hidup sejahtera lahir dan batin,bertempat tinggal, dan mendapatkan lingkungan yang baik dan sehat serta memperoleh pelayanan kesehatan". Hal ini dapat dimaknai bahwa perumahan dan kawasan permukiman yang baik dan sehat merupakan hak dasar bagi setiap warga negara yang harus dijamin oleh negara dan menjadi tanggung jawab Negara. Peraturan Menteri Pekerjaan Umum dan Perumahan Rakyat Republik Indonesia Nomor 02/PRT/M/2016 tentang Peningkatan Kualitas Terhadap Perumahan Kumuh dan Permukiman Kumuh, bahwa dalam rangka meningkatkan mutu kehidupan dan penghidupan masyarakat melalui perumahan dan permukiman yang sehat, aman, serasi, dan teratur dibutuhkan analisis peningkatan kualitas terhadap perumahan kumuh dan permukiman kumuh. Revitalisasi merupakan upaya untuk memvitalkan kembali suatu kawasan yang dulunya pernah vital / hidup akan tetapi mengalami kemunduran atau degradasi (Cyntia, 2019). Revitalisasi kawasan dilakukan melalui pengembangan kawasan-kawasan tertentu yang layak untuk direvitalisasi baik dari segi setting kawasan (bangunan dan ruang kawasan), kualitas lingkungan dan utilitas kawasan. Umumnya kegiatan revitalisasi lebih kepada pengendalian kawasan permukiman yang tidak terkendali oleh adanya aktivitas kawasan itu sendiri. Hilangnya vitalitas awal dalam suatu kawasan permukiman yang ditandai dengan kurang terkendalinya perkembangan dan pembangunan kawasan, sehingga mengakibatkan terjadinya kehancuran kawasan, baik secara self destruction maupun creative destruction (Danisworo, 2000). Urgensi revitalisasi dapat diukur berdasarkan tingkat kekumuhan kawasan, yaitu melalui beberapa parameter fisik kawasan (tata bangunan, penyediaan air bersih, pengelolaan air limbah, fasilitas drainase, dan jalan lingkungan), non fisik kawasan (pemilikan hak atas lahan, kepadatan penduduk).

Beberapa tahun terakhir ini perhatian masyarakat Kota Makassar terhadap lingkungan permukiman bertambah besar, dilihat dari banyaknya ceramah, seminar, rapat kerja dan pertemuan diselenggarakan oleh berbagai kalangan pemerintah maupun masyarakat. Masalah lingkungan permukiman ini merupakan masalah yang pelik dan berkaitan satu sama lain, sehingga penanggulangannya harus dilaksanakan secara terpadu melalui berbagai kebijaksanaan, strategi, perencanaan yang dilaksanakan secara konsisten dan berkelanjutan (sustainable). Diperkirakan kurang lebih 8.322 jumlah rumah tangga (RP2KPKP Kota Makassar, 2016) penduduk Kota Makassar bertempat tinggal di permukiman kumuh dengan kategori berat, dimana keadaan fisik dan sosial ekonomi tidak memenuhi persyaratan kesehatan. Pemerintah Kota Makassar sudah berusaha keras untuk memperbaiki lingkungan permukiman ini melalui proyek-proyek atau program pembangunan sarana/prasarana kota, seperti pelebaran dan peningkatan jalan, permukiman penduduk, perbaikan saluran air di tepi jalan raya, pusat - pusat pertokoan/perbelanjaan, gedung sekolah, sarana kesehatan dan sebagainya. Namun hal tersebut belum dapat dilaksanakan secara menyeluruh mengingat keterbatasan biaya, peralatan dan fasilitas lainnya.

Berbicara mengenai kualitas lingkungan permukiman, Kelurahan Tallo merupakan daerah di kawasan pesisir yang nampaknya patut diperhatikan. Sebagian masyarakat hidup dengan kualitas lingkungan permukiman yang dikategorikan termasuk kumuh berat (SK Kumuh) permukiman kumuh diatas air. Tidak dapat dipungkiri bahwa kondisi lingkungan permukiman itu dapat dilihat pada rumah penduduk yang merupakan bangunan yang tidak permanen, perumahan yang berada diatas air, jalan-jalan yang belum diaspal, sulitnya air bersih dan saluran air yang tidak teratur, pembuangan sampah/kotoran sembarangan serta perilaku warga yang tidak mempertimbangkan kebersihan maupun kesehatan dengan membuang air limbah rumah tangga di sungai mengakibatkan sampah yang menumpuk dan bau kotor/jorok tak terbendung lagi. Gambaran tersebut patut untuk dikaji bagaimana penilaian masyarakat tentang upaya peningkatan kualitas lingkungan permukiman kumuh di Kelurahan Tallo Kecamatan Tallo. Kelurahan Tallo yang terletak di Kecamatan Tallo merupakan salah satu kecamatan terbesar di Kota Makassar. Hal ini sebanding dengan kepadatan penduduk yang tinggi, sehingga tidak heran jika Kelurahan Tallo memiliki kondisi permukiman yang dapat di kategorikan kumuh sesuai dengan parameter yang telah dijelaskan diatas. Berdasarkan uraian tersebut perlu dilakukan analisis peningkatan kualitas permukiman kumuh di Kelurahan Tallo Kota Makassar untuk mengidentifikasi penyebab permukiman kumuh dan mengetahui strategi peningkatan kualitas permukiman kumuh di Kelurahan Tallo Kota Makassar. 


\section{METODE}

\subsection{Teknik Pengumpulan Data}

Teknik pengumpulan data yang digunakan dalam penelitian ini berupa studi kepustakaan dan studi lapangan. Studi lapangan dilakukan melalui observasi, wawancara, dan kuesioner.

\subsection{Variabel Penelitian}

Variabel penelitian yang digunakan pada penelitian ini terdiri dari 5 unsur sistem permukiman (Dixioadis, 1969) meliputi jejaring, drainase, air minum, air limbah, dan persampahan

Tabel 1. Variabel Penelitian

\begin{tabular}{|c|c|c|}
\hline Variabel $(\mathbf{X})$ & Sub Variabel $(X n)$ & Indikator \\
\hline \multirow[t]{4}{*}{ Jejaring (Network) } & Drainase $\left(\mathrm{X}_{1}\right)$ & $\begin{array}{l}\text { - } \text { Ketidaktersediaan Drainase } \\
\text { - Tidak Terpeliharanya Drainase } \\
\text { - Kualitas Konstruksi Drainase }\end{array}$ \\
\hline & Air Minum $\left(\mathrm{X}_{2}\right)$ & - Tidak Terpenuhinya air Minum \\
\hline & Air Limbah $\left(\mathrm{X}_{3}\right)$ & $\begin{array}{l}\text { - Sistem Pengelolaan Air limbah tidak sesuai standar teknis } \\
\text { - Prasarana dan sarana pengelolaan air limbah tidak sesuai } \\
\text { standar teknis }\end{array}$ \\
\hline & Persampahan $\left(\mathrm{X}_{4}\right)$ & $\begin{array}{l}\text { - Prasarana dan Sarana Persampahan Tidak Sesuai Standar } \\
\text { Teknis } \\
\text { - Sistem Pengelolaan Persampahan Tidak Sesuai Jenis }\end{array}$ \\
\hline
\end{tabular}

\subsection{Metode Analisis}

Metode analisis yang digunakan dalam penelitian ini yaitu menggunakan metode analisis chi-square untuk melihat faktor determinan yang menggambarkan karakteristik faktor-faktor yang mempengaruhi dari variabel yang diteliti (Pribadi, 2019). Kemudian untuk menyusun rumusan alternatif strategi analisis peningkatan kualitas permukiman kumuh di Kelurahan Tallo menggunakan analisis faktor-faktor internal dan eksternal (IFE-EFE), matriks IE, serta analisis SWOT.

\section{HASIL DAN PEMBAHASAN}

\subsection{Analisis Peningkatan Kualitas Permukiman Kumuh di Kelurahan Tallo, Kecamatan Tallo, Makassar}

a. Drainase

Berdasarkan observasi dan penilaian dari indikator seperti ketidaktersediaan drainase, tidak terpeliharanya drainase dan kualitas konstruksi drainase yang telah ditetapkan bahwa drainase yang ada di lingkungan tersebut masuk dengan penilaian tingkat kumuh sedang.

Tabel 2. Kondisi Drainase, Kelurahan Tallo RW 4 RT 1-6

\begin{tabular}{cccccc}
\hline No & RTRW & $\begin{array}{c}\text { Drainase } \\
\text { Eksisting } \\
\text { (Meter/Unit) }\end{array}$ & $\begin{array}{c}\text { Ketidaktersediaan } \\
\text { Drainase } \\
\text { (Meter/Unit/Ruas) }\end{array}$ & $\begin{array}{c}\text { Drainase Tidak } \\
\text { Terpelihara } \\
\text { (Meter) }\end{array}$ & $\begin{array}{c}\text { Kualitas Konstruksi } \\
\text { Drainase (Meter) }\end{array}$ \\
\hline 1 & RT001-RW004 & 352 & 0 & 352 & 0 \\
2 & RT002-RW004 & 204 & 0 & 35 & 154 \\
3 & RT003-RW004 & 513.1 & 0 & 276.1 & 105.85 \\
4 & RT004-RW004 & 290 & 150 & 140 & 140 \\
5 & RT005-RW004 & 226 & 0 & 143.24 & 143.24 \\
6 & RT006-RW004 & 308.27 & 0 & 218.17 & 218.17 \\
\hline
\end{tabular}

Sumber: Survey Lapangan Kelurahan Tallo, 2020 
b. Air Minum

1) Sumber Air Minum Terhadap Kekumuhan

Tabel 3. Uji Chi Kuadrat Sumber Air Minum Terhadap Kekumuhan

\begin{tabular}{|c|c|c|c|c|c|c|c|c|c|c|c|c|}
\hline & & \multicolumn{3}{|c|}{$\mathbf{X}$} & \multirow{2}{*}{$\Sigma$} & \multicolumn{3}{|c|}{$\mathbf{F}_{\mathbf{h}}$} & \multicolumn{3}{|c|}{$\mathbf{X}^{2}$} & \multirow{2}{*}{$\sum$} \\
\hline & & 1 & 2 & 3 & & 1 & 2 & 3 & 1 & 2 & 3 & \\
\hline \multirow[b]{2}{*}{$\mathbf{Y}$} & 1 & 33 & 50 & - & 83 & 27.39 & 46.48 & 9.13 & 1.15 & 0.27 & 9.13 & 10.55 \\
\hline & 2 & - & 6 & 11 & 17 & 5.61 & 9.52 & 1.87 & 5.61 & 1.30 & 44.58 & 51.49 \\
\hline$\sum$ & & 33 & 56 & 11 & 100 & & & & & & & \\
\hline$\overline{\mathbf{X}}^{2}$ & & & & & & & & & & & & 62.03 \\
\hline Db & & & & & & & & & & & & 2 \\
\hline A & & & & & & & & & & & & 0.05 \\
\hline $\mathrm{X}^{2}$ Tabel & & & & & & & & & & & & 5.991 \\
\hline
\end{tabular}

Sumber: Hasil Analisis, 2020

Berdasarkan survey dan tabel 3.2 diatas, dapat dilihat bahwa Sumber Air Minum menurut uji chi kuadrat berpengaruh terhadap kekumuhan di Kelurahan Tallo. Untuk mengukur tingkat pengaruh sumber air minum terhadap kekumuhan di Kelurahan Tallo maka selanjutnya dilakukan uji kontingensi dimana :

C: $\sqrt{\left.\frac{X^{2}}{\left(N+X^{2}\right)}\right)}$

$C: \sqrt{\left.\frac{15.13^{2}}{\left(100+15.13^{2}\right)}\right)}$

: 0.62 atau Berpengaruh Kuat

2) Kebutuhan Air Minum Terhadap Kekumuhan

Tabel 4. Uji Chi Kuadrat Kebutuhan Air Minum Terhadap Kekumuhan

\begin{tabular}{|c|c|c|c|c|c|c|c|c|c|c|c|c|}
\hline & & \multicolumn{3}{|c|}{$\mathbf{X}$} & \multirow{2}{*}{$\Sigma$} & \multicolumn{3}{|c|}{$\mathbf{F}_{\mathbf{h}}$} & \multicolumn{3}{|c|}{$X^{2}$} & \multirow{2}{*}{$\Sigma$} \\
\hline & & 1 & 2 & 3 & & 1 & 2 & 3 & 1 & 2 & 3 & \\
\hline \multirow{2}{*}{$\mathbf{Y}$} & 1 & 32 & 51 & - & 83 & 26.56 & 47.31 & 9.13 & 1.30 & 0.21 & 9.02 & 10.53 \\
\hline & 2 & - & 6 & 11 & 17 & 5.44 & 9.69 & 1.87 & 5.94 & 0.94 & 41.09 & 51.42 \\
\hline$\sum$ & & 32 & 57 & 11 & 100 & & & & & & & \\
\hline$X^{2}$ & & & & & & & & & & & & 61.95 \\
\hline Db & & & & & & & & & & & & 2 \\
\hline A & & & & & & & & & & & & 0.05 \\
\hline $\mathrm{X}^{2}$ Tabel & & & & & & & & & & & & 5.991 \\
\hline
\end{tabular}

Sumber: Hasil Analisis, 2020

Berdasarkan survey dan tabel 3.3 diatas, dapat dilihat bahwa Kebutuhan Air Minum menurut uji chi kuadrat berpengaruh terhadap kekumuhan di Kelurahan Tallo. Untuk mengukur tingkat pengaruh Kebutuhan air minum terhadap kekumuhan di Kelurahan Tallo maka selanjutnya dilakukan uji kontingensi dimana :

$$
\begin{aligned}
& \text { C: } \sqrt{\left.\frac{X^{2}}{\left(N+X^{2}\right)}\right)} \\
& \text { C: } \sqrt{\left.\frac{15.13^{2}}{\left(100+15.13^{2}\right)}\right)} \\
& =0.62 \text { atau Berpengaruh Kuat }
\end{aligned}
$$


c. Air Limbah

1) Sistem Pengelolaan Air Limbah Terhadap Kekumuhan

Tabel 5. Uji Chi Kuadrat Sistem Pengelolaan Air Limbah Terhadap Kekumuhan

\begin{tabular}{|c|c|c|c|c|c|c|c|c|c|c|c|c|}
\hline & & \multicolumn{3}{|c|}{$\mathbf{X}$} & \multirow{2}{*}{$\Sigma$} & \multicolumn{3}{|c|}{$\mathbf{F}_{\mathbf{h}}$} & \multicolumn{3}{|c|}{$\mathbf{X}^{2}$} & \multirow{2}{*}{$\sum$} \\
\hline & & 1 & 2 & 3 & & 1 & 2 & 3 & 1 & 2 & 3 & \\
\hline \multirow{2}{*}{$\mathbf{Y}$} & 1 & 60 & 0 & 23 & 83 & 49.8 & 0 & 33.2 & 2.09 & 0 & 3.13 & 5.22 \\
\hline & 2 & 0 & 0 & 17 & 17 & 10.2 & 0 & 6.8 & 10.20 & 0 & 15.30 & 25.50 \\
\hline$\sum$ & & 33 & 56 & 11 & 100 & & & & & & & \\
\hline $\mathbf{X}^{2}$ & & & & & & & & & & & & 30.72 \\
\hline db & & & & & & & & & & & & 2 \\
\hline$\alpha$ & & & & & & & & & & & & 0.05 \\
\hline $\mathrm{X}^{2}$ Tabel & & & & & & & & & & & & 5.991 \\
\hline
\end{tabular}

Sumber: Hasil Analisis, 2020

Berdasarkan survey dan tabel 3.4 diatas, dapat dilihat bahwa sistem Pengelolaan Air Limbah menurut uji chi kuadrat berpengaruh terhadap kekumuhan di Kelurahan Tallo. Adapun Untuk mengukur pengaruh sistem Pengelolaan air limbah terhadap kekumuhan di Kelurahan Tallo maka selanjutnya dilakukan uji kontingensi dimana:

$$
\begin{aligned}
& \mathrm{C}: \sqrt{\left.\frac{X^{2}}{\left(N+X^{2}\right)}\right)} \\
& \mathrm{C}: \sqrt{\left.\frac{15.13^{2}}{\left(100+15.13^{2}\right)}\right)} \\
& : 0.48 \text { atau Berpengaruh Lemah }
\end{aligned}
$$

\begin{tabular}{|c|c|c|c|c|c|c|c|c|c|}
\hline & & \multicolumn{2}{|c|}{$\mathbf{X}$} & \multirow{2}{*}{$\Sigma$} & \multicolumn{2}{|c|}{$\mathbf{F}_{\mathbf{h}}$} & \multicolumn{2}{|c|}{$\mathbf{X}^{2}$} & \multirow{2}{*}{$\sum$} \\
\hline & & 1 & 2 & & 1 & 2 & 1 & 2 & \\
\hline \multirow{2}{*}{$\mathbf{Y}$} & 1 & 76 & 7 & 83 & 63.08 & 19.92 & 2.65 & 8.38 & 11.03 \\
\hline & 2 & 0 & 17 & 17 & 12.92 & 4.08 & 12.92 & 40.91 & 53.83 \\
\hline$\sum$ & & 76 & 24 & 100 & & & & & \\
\hline $\mathbf{X}^{2}$ & & & & & & & & & 64.86 \\
\hline db & & & & & & & & & 1 \\
\hline $\boldsymbol{\alpha}$ & & & & & & & & & 0.05 \\
\hline $\mathrm{X}^{2}$ Tabel & & & & & & & & & 0.004 \\
\hline
\end{tabular}

2) Jenis Kloset Terhadap Kekumuhan

Tabel 6. Uji Chi Kuadrat Jenis Kloset Terhadap Kekumuhan

Kesimpulan

Sumber: Hasil Analisis, 2020

Berdasarkan survey dan tabel 4.3, dapat dilihat bahwa Jenis Kloset menurut uji chi kuadrat berpengaruh terhadap kekumuhan di Kelurahan Tallo. Untuk mengukur tingkat pengaruh Jenis Kloset terhadap kekumuhan di Kelurahan Tallo maka selanjutnya dilakukan uji kontingensi dimana :

$$
\begin{aligned}
C & =\sqrt{\left.\frac{X^{2}}{\left(N+X^{2}\right)}\right)} \\
C & =\sqrt{\left.\frac{15.13^{2}}{\left(100+15.13^{2}\right)}\right)} \\
& =0.63 \text { atau Berpengaruh Kuat }
\end{aligned}
$$

3) Pembuangan Limbah Terhadap Kekumuhan 
Tabel 7. Uji Chi Kuadrat Pembuangan Limbah Terhadap Kekumuhan

\begin{tabular}{|c|c|c|c|c|c|c|c|c|c|c|c|c|}
\hline \multirow[b]{2}{*}{$\mathbf{Y}$} & & \multicolumn{3}{|c|}{$\mathbf{X}$} & \multirow{2}{*}{$\Sigma$} & \multicolumn{3}{|c|}{$\mathbf{F}_{\mathrm{h}}$} & \multicolumn{3}{|c|}{$\mathbf{X}^{2}$} & \multirow{2}{*}{$\sum$} \\
\hline & & 1 & 2 & 3 & & 1 & 2 & 3 & 1 & 2 & 3 & \\
\hline \multirow{2}{*}{$\mathbf{Y}$} & 1 & 46 & 37 & 0 & 83 & 38.18 & 44.82 & 0 & 1.60 & 1.36 & 0 & 2.97 \\
\hline & 2 & 0 & 17 & 0 & 17 & 7.82 & 9.18 & 0 & 7.82 & 6.66 & 0 & 14.48 \\
\hline$\Sigma$ & & 46 & 54 & 0 & 100 & & & & & & & \multirow{3}{*}{$\begin{array}{c}\mathbf{1 7 . 4 5} \\
\\
2 \\
0.05 \\
\mathbf{5 . 9 9 1}\end{array}$} \\
\hline $\mathbf{X}^{2}$ & & & & & & & & & & & & \\
\hline & & & & & & & & & & & & \\
\hline \multicolumn{9}{|c|}{ Kesimpulan } & \multicolumn{4}{|c|}{ Berpengaruh } \\
\hline
\end{tabular}

Sumber: Hasil Analisis, 2020

Berdasarkan survey dan tabel 3.6 diatas, dapat dilihat bahwa Pembuangan Limbah menurut uji chi kuadrat berpengaruh terhadap kekumuhan di Kelurahan Tallo. Untuk mengukur tingkat pengaruh Pembuangan Limbah terhadap kekumuhan di Kelurahan Tallo maka selanjutnya dilakukan uji kontingensi dimana :

$$
\begin{aligned}
& \mathrm{C}: \sqrt{\left.\frac{X^{2}}{\left(N+X^{2}\right)}\right)} \\
& C: \sqrt{\left.\frac{15.13^{2}}{\left(100+15.13^{2}\right)}\right)} \\
& : 0.39 \text { atau Berpengaruh Lemah }
\end{aligned}
$$

d. Persampahan

\begin{tabular}{|c|c|c|c|c|c|c|c|c|c|c|c|c|}
\hline & & \multicolumn{3}{|c|}{$\mathbf{X}$} & \multirow{2}{*}{$\Sigma$} & \multicolumn{3}{|c|}{$F_{h}$} & \multicolumn{3}{|c|}{$\mathrm{X}^{2}$} & \multirow{2}{*}{$\Sigma$} \\
\hline & & 1 & 2 & 3 & & 1 & 2 & 3 & 1 & 2 & 3 & \\
\hline \multirow[b]{2}{*}{$\mathbf{Y}$} & 1 & 0 & 55 & 28 & 83 & 0 & 45.65 & 37.35 & & 1.92 & 2.34 & 4.26 \\
\hline & 2 & 0 & 0 & 17 & 17 & 0 & 9.35 & 7.65 & & 9.35 & 11.43 & 20.78 \\
\hline$\Sigma$ & & 0 & 55 & 45 & 100 & 0 & & & & & & \\
\hline $\begin{array}{c}\mathbf{X}^{2} \\
\mathbf{d b} \\
\alpha \\
\mathbf{X}^{2} \text { Tabel }\end{array}$ & & & & & & & & & & & & $\begin{array}{c}\mathbf{2 5 . 0 3} \\
\\
2 \\
0.05 \\
\mathbf{5 . 9 9 1}\end{array}$ \\
\hline
\end{tabular}

1) Tempat Pembuangan Sampah Terhadap Kekumuhan

Tabel 8. Uji Chi Kuadrat Tempat Pembuangan Sampah Terhadap Kekumuhan

Sumber: Hasil Analisis, 2020

Berdasarkan survey dan tabel 3.7 diatas, dapat dilihat Tempat Pembuangan Sampah menurut uji chi kuadrat berpengaruh terhadap kekumuhan di Kelurahan Tallo. Untuk mengukur tingkat pengaruh Tempat Pembuangan Sampah terhadap kekumuhan di Kelurahan Tallo maka selanjutnya dilakukan uji kontingensi dimana :

$$
\begin{aligned}
& \text { C: } \sqrt{\left.\frac{X^{2}}{\left(N+X^{2}\right)}\right)} \\
& C: \sqrt{\left.\frac{15.13^{2}}{\left(100+15.13^{2}\right)}\right)} \\
& : 0.45 \text { atau Berpengaruh Lemah }
\end{aligned}
$$

2) Waktu Pengangkutan Sampah Terhadap Kekumuhan 
Tabel 9. Uji Chi Kuadrat Waktu Pengangkutan Sampah Terhadap Kekumuhan

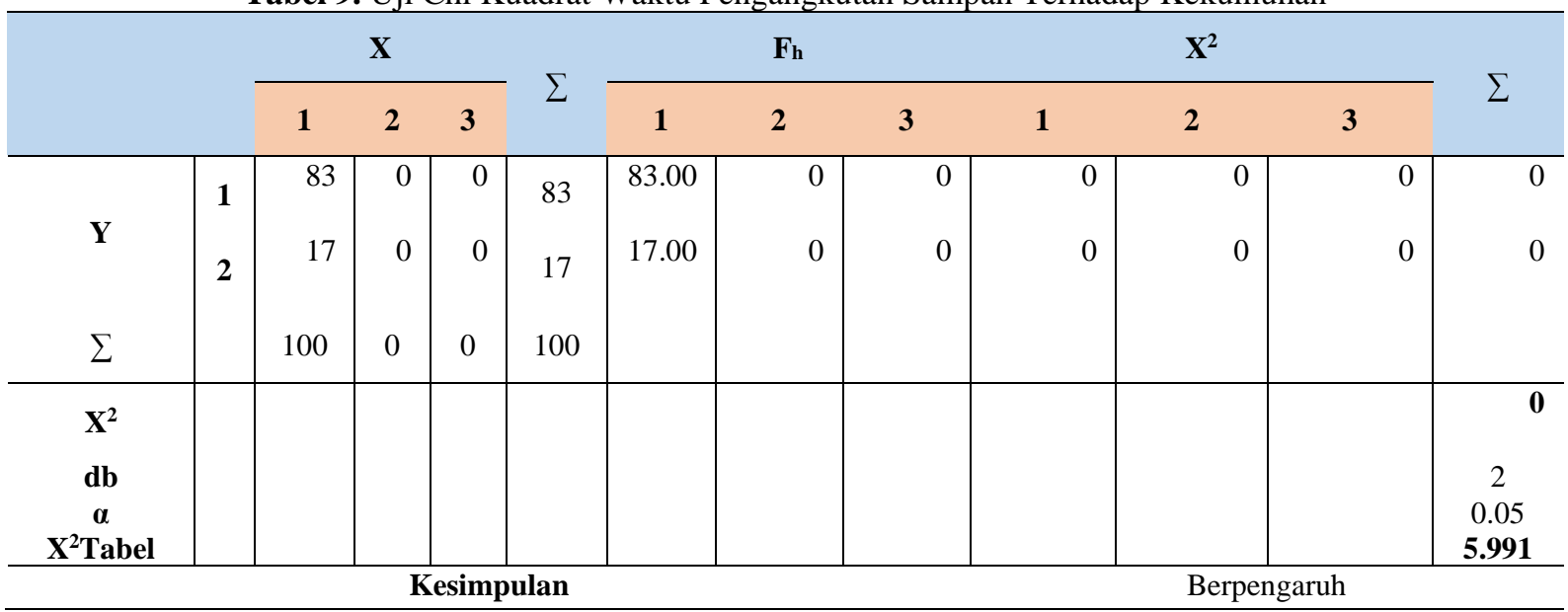

Sumber: Hasil Analisis, 2020

Berdasarkan survey dan tabel 3.8 diatas, dapat dilihat bahwa Waktu Pengangkutan Sampah menurut uji chi kuadrat berpengaruh terhadap kekumuhan di Kelurahan Tallo. Untuk mengukur tingkat pengaruh waktu pengangkutan sampah terhadap kekumuhan di Kelurahan Tallo maka selanjutnya dilakukan uji kontingensi dimana :
C: $\sqrt{\left.\frac{X^{2}}{\left(N+X^{2}\right)}\right)}$
$C: \sqrt{\left.\frac{15.13^{2}}{\left(100+15.13^{2}\right)}\right)}$

\subsection{Analisis Strategi Peningkatan Kualitas Permukiman Kumuh di Kelurahan Tallo Kecamatan Tallo RW \\ 1-4}

Analisis SWOT ( Strenghts, Weaknes, Opportunities, Threads) digunakan dalam menjawab rumusan masalah kedua yaitu bagaimana strategi peningkatan kualitas permukiman kumuh di Kelurahan Tallo Kota Makassar. Hasil yang diperoleh berdasarkan analisis SWOT adalah sebagai berikut:

Tabel 10. Matriks SWOT

\begin{tabular}{|c|c|}
\hline Kekuatan (S) & Kelemahan (W) \\
\hline $\begin{array}{l}\text { 1. Masyarakat sangat mendukung program } \\
\text { pemerintah terkait kegiatan peningkatan } \\
\text { kualitas lingkungan permukimannya }\end{array}$ & $\begin{array}{l}\text { 1. Tidak memadai sistem drainase } \\
\text { 2. Ketersediaan pengelolan air limbah yang } \\
\text { kurang memadai }\end{array}$ \\
\hline $\begin{array}{l}\text { 2. Adanya kesadaran masyarakat dalam } \\
\text { meningkatkan kualitas }\end{array}$ & $\begin{array}{l}\text { 3. Tidak terpenuhinya air minum } \\
\text { 4. Sistem persampahan yang buruk }\end{array}$ \\
\hline 3. Jaringan jalan yang memadai & \\
\hline $\begin{array}{l}\text { 4. Lokasi memiliki potensi sosial ekonomi untuk } \\
\text { dikembangkan }\end{array}$ & \\
\hline Peluang $(\mathbf{O})$ & Ancaman (T) \\
\hline $\begin{array}{l}\text { 1. SK MENTRI NO 534/KTPS/M/2001 Tentang } \\
\text { penataan permukiman }\end{array}$ & $\begin{array}{l}\text { 1. Terjadinya genangan air pada saat musim } \\
\text { hujan }\end{array}$ \\
\hline $\begin{array}{l}\text { 2. Permen PU NO } 2 \text { Tahun } 2016 \text { tentang } \\
\text { peningkatan kualitas perumahan dan } \\
\text { permukiman kumuh }\end{array}$ & $\begin{array}{l}\text { 2. Meningkatnya potensi kebakaran akibat } \\
\text { kurangnya proteksi kebakaran dan rumah } \\
\text { yang terlalu berdekatan }\end{array}$ \\
\hline $\begin{array}{l}\text { 3. RTRW KOTA MAKASSAR 2015-2035 } \\
\text { tentang Pengembangan, peningkatan, } \\
\text { pemantapan, dan rehabilitasi jaringan jalan }\end{array}$ & $\begin{array}{l}\text { 3. Kekurangan air bersih akibat pencemaran } \\
\text { air yang terjadi } \\
\text { 4. Sedimentasi pada saluran drainase }\end{array}$ \\
\hline $\begin{array}{l}\text { 4. Terdapatnya program pemberdayaan } \\
\text { masyarakat (RP2KPKP, KOTAKU, dan SK } \\
\text { Kumuh Walikota 2015) }\end{array}$ & \\
\hline
\end{tabular}

Sumber: Survey Lapangan dan Analisis, 2020 
Tabel 11. Nilai Skor IFAS

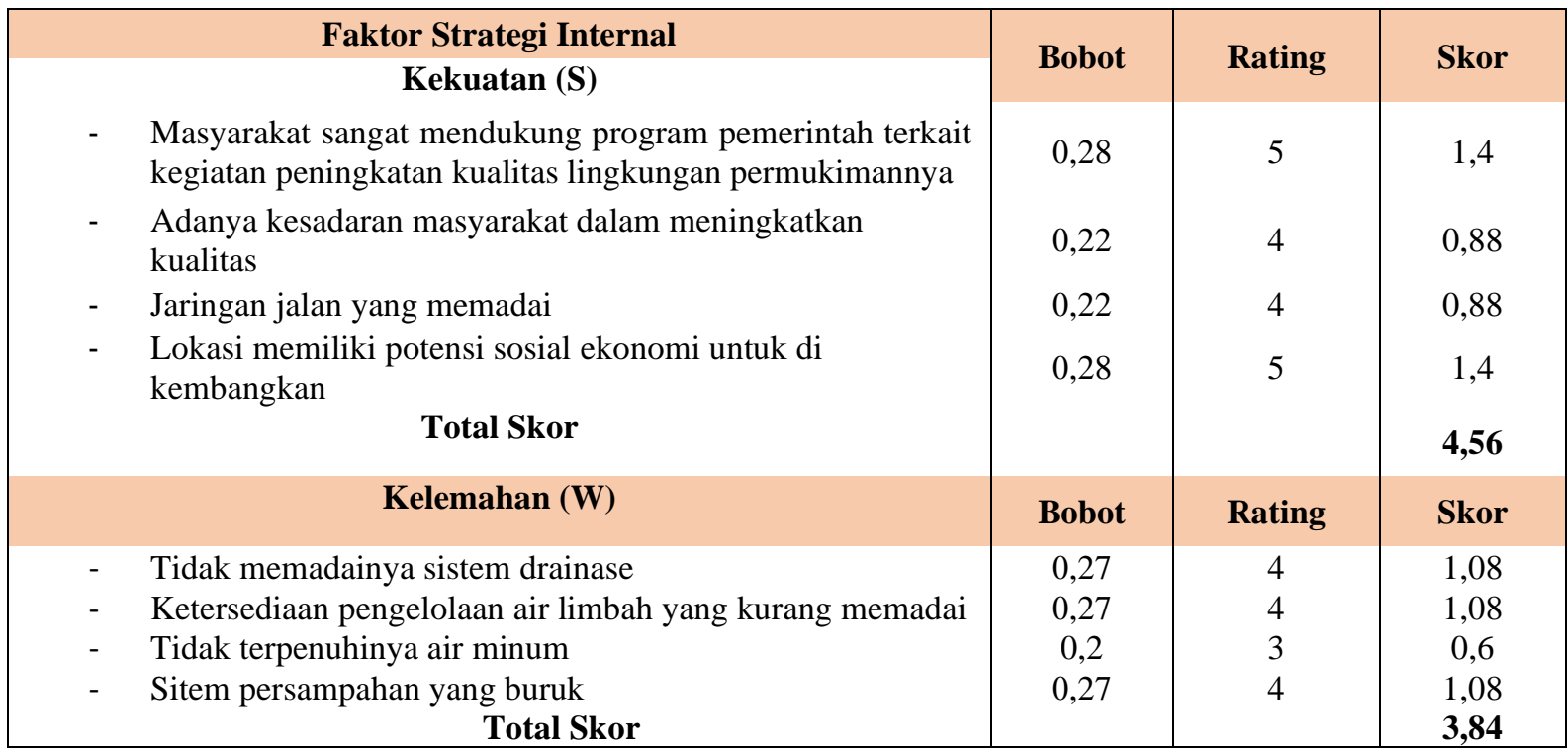

Tabel 12. Nilai Skor EFAS

\begin{tabular}{|c|c|c|c|}
\hline Faktor Strategi Eksternal & \multirow{2}{*}{ Bobot } & \multirow{2}{*}{ Rating } & \multirow{2}{*}{ Skor } \\
\hline \multirow{5}{*}{ 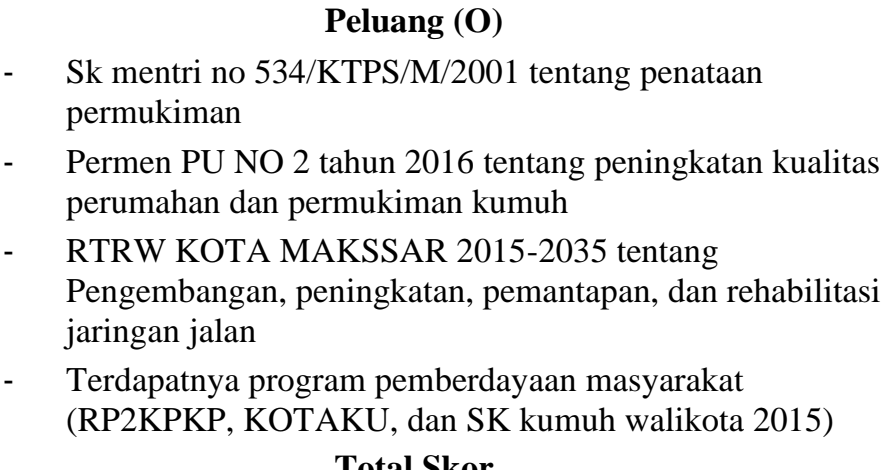 } & & & \\
\hline & 0,26 & 5 & 1,3 \\
\hline & 0,26 & 5 & 1,3 \\
\hline & 0,21 & 4 & 0,84 \\
\hline & 0,26 & 5 & 1,3 \\
\hline & & & 4,74 \\
\hline Ancaman (T) & Bobot & Rating & Skor \\
\hline - $\quad$ Terjadinya genangan air pada saat musim hujan & 0,29 & 4 & 1,16 \\
\hline $\begin{array}{l}\text { - Meningkatnya potensi kebakaran akibat kurangnya } \\
\text { proteksi kebakaran dan rumah yang terlalu berdekatan }\end{array}$ & 0,21 & 3 & 0,63 \\
\hline - $\quad$ Kekurangan air bersih akibat pencemaran air yang terjadi & 0,21 & 3 & 0,63 \\
\hline - $\quad$ Sedimentasi pada saluran drainase & 0,29 & 4 & 1,16 \\
\hline Total Skor & & & 3,58 \\
\hline
\end{tabular}

Kesimpulan:

1. (IFAS) Hasil kekuatan - kelemahan $=4,56-3,84=0,72$

2. (EFAS) Hasil peluang - ancaman $=4,74-3,58=1,16$

\subsection{Strategi Peningkatan Kualitas Permukiman Kumuh di Kelurahan Tallo Kecamatan Tallo}

Berdasarkan hasil analisis SWOT di atas, rumusan strategi dalam meningkatkan kualitas permukiman kumuh adalah dengan strategi SO yaitu memaksimalkan kekuatan dan peluang dalam meminimalkan kelemahan dan ancaman. Adapun strateginya yaitu :

a. Memanfaatkan Masyarakat yang mendukung program pemerintah terkait kegiatan peningkatan kualitas lingkungan permukimannya dengan adanya SK MENTRI NO 534/KTPS/M/200 Tentang penataan permukiman.

b. Memanfaatkan kesadaran masyarakat dalam meningkatkan kualitas Permukiman Kumuh sesuai dengan Permen PU NO 2 Tahun 2016 tentang peningkatan kualitas perumahan dan permukiman kumuh 
c. Merawat Jaringan jalan yang sudah ada seperti pada RTRW KOTA MAKASSAR 2015-2035 tentang Pengembangan, peningkatan, pemantapan,dan rehabilitasi jaringan jalan.

d. Meningkatkan potensi sosial ekonomi masyarakat sekitar dengan program pemberdayaan masyarakat (RP2KPKP, KOTAKU, dan SK Kumuh Walikota 2015)

\section{KESIMPULAN}

Setelah melakukan beberapa tahapan dan proses penelitian, menghasilkan pembahasan dan analisis yang telah dilakukan sebelumnya maka dari penelitian ini dapat ditarik kesimpulan bahwa faktor yang menyebabkan permukiman kumuh di Kelurahan Tallo Kota Makassar adalah Drainase, Air Minum, Air limbah, dan Persampahan. Diperoleh bahwa semua variabel tersebut memiliki pengaruh terhadap penyebab kekumuhan di Kelurahan Tallo. Faktor sumber air minum dan kebutuhan air minum berpengaruh kuat, sedangkan faktor air limbah dan persampahan berpengaruh sedang terhadap penyebab kekumuhan.

Strategi peningkatan kualitas permukiman kumuh di Kelurahan Tallo Kota Makassar adalah memanfaatkan Masyarakat yang mendukung program pemerintah terkait kegiatan peningkatan kualitas lingkungan permukimannya dengan adanya SK MENTRI NO 534/KTPS/M/200 Tentang penataan permukiman; memanfaatkan kesadaran masyarakat dalam meningkatkan kualitas Permukiman Kumuh sesuai dengan Permen PU NO 2 Tahun 2016 tentang peningkatan kualitas perumahan dan permukiman kumuh; merawat Jaringan jalan yang sudah ada seperti pada RTRW KOTA MAKASSAR 2015-2035 tentang Pengembangan, peningkatan, pemantapan,dan rehabilitasi jaringan jalan; serta meningkatkan potensi sosial ekonomi masyarakat sekitar dengan program pemberdayaan masyarakat (RP2KPKP, KOTAKU, dan SK Kumuh Walikota 2015).

\section{DAFTAR PUSTAKA}

Cyntia, K.P. (2019). Analisis Efektivitas Program Revitalisasi Pasar Tradisional dan Dampaknya terhadap Pendapatan Pedagang dan Pengelolaan Pasar Pohgading. Jurnal Ekonomi dan Bisnis Universitas Udayana, 9(7) : 805-834

Danisworo, M dan Martokusumo,W. (2000). Revitalisasi Kawasan Kota Sebuah Catatan dalam Pengembangan dan Pemanfaatan Kawasan Kota

Doxiadis, Constantinos. (1969). EKISTICS an Introduction to The Science of Human Settlement, London.

Permen PU No 2 Tahun 2016 Tentang Peningkatan Kualitas Perumahan Dan Permukiman Kumuh

Pribadi, E.M. (2008). Chi Square Test. Jakarta : Universitas Gunadarma

Rencana Pencegahan dan Peningkatan Kualitas Permukiman Kumuh Perkotaan Kota Makassar, 2016

Undang-Undang No.1 Tahun 2011 Tentang Perumahan Dan Kawasan Permukiman 